\title{
Erratum
}

\section{Binding of Concanavalin A to Intact Cells and Speroplasts of Anacystis nidulans}

F. S. Hauser and G. A. Peschek

Current Microbiol 7:377-382, 1982

During the production process, an unrevised figure was mistakenly printed above the legend for Fig. 2 . To the right is the correct figure as it should have appeared:

Fig. 2. $\mathrm{pH}$ Dependence of FITC-ConA binding to Anacystis nidulans. Cells were preincubated with $0.05 \%$ (wt/vol) CTAB at $22^{\circ} \mathrm{C}$ and $\mathrm{pH} 7.0$ for $30 \mathrm{~min}$, centrifuged, and washed free of $\mathrm{CTAB}$. Washed cells were incubated, at different $\mathrm{pH}$ values, with $10 \mu \mathrm{g} / \mathrm{ml}$ of FITC-ConA at $22^{\circ} \mathrm{C}$ for $60 \mathrm{~min}$.

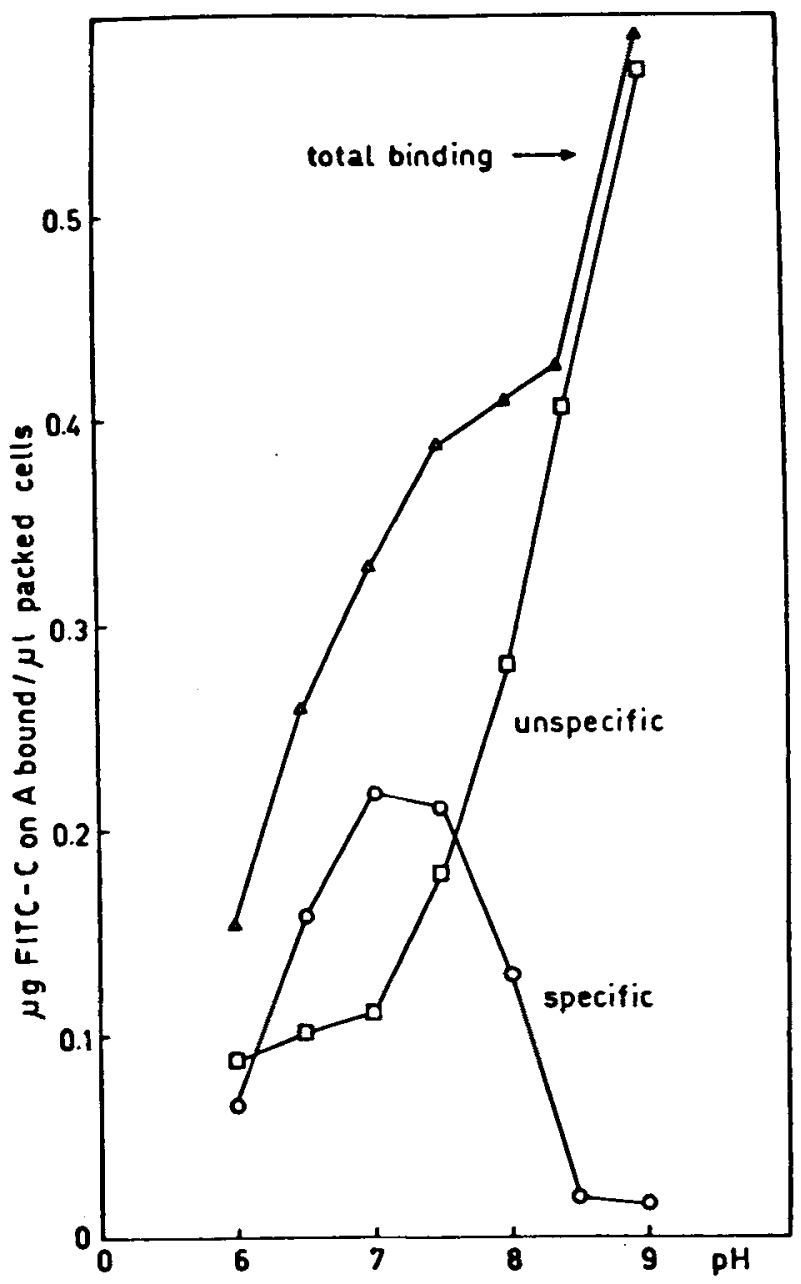

